See discussions, stats, and author profiles for this publication at: https://www.researchgate.net/publication/ 337491700

\title{
Brand New Identity: A Gynocritical Reading of Entrok and Amba
}

Conference Paper · November 2019

DOI: 10.4108/eai.19-7-2019.2289538

CITATION

1

3 authors, including:

(2) Yenni Hayati

Universitas Negeri Padang

40 PUBlications 29 CITATIONS

SEE PROFILE

Some of the authors of this publication are also working on these related projects:

Project ICLLE 2019 View project

\section{READS}

22

Muhammad Adek

Universitas Negeri Padang

22 PUBLICATIONS 6 CITATIONS

SEE PROFILE 


\title{
'BRAND NEW IDENTITY: A GYNOCRITICAL READING OF ENTROK \& AMBA
}

\author{
Asri $Y^{\mathbf{1}}$, Hayati $\mathbf{Y}^{\mathbf{2}}$, Adek $\mathbf{M}^{\mathbf{3}}$ \\ \{yasnurasri5@gmail.com ${ }^{1}$, yennihayati@fbs.unp.ac.id ${ }^{2}, \underline{\text { marximalize@ } @ \text { fbs.unp.ac.id }}^{3}$ \} \\ Faculty of Languages and Arts \\ Universitas Negeri Padang ${ }^{1,2,3}$
}

\begin{abstract}
Contructed identity about women has passed down from generation to generation in common Indonesian literature is feminine. However, contemporary Indonesian women writers through their works these days has been trying to reconstruct this given identity with something new in accordance with recent reality and current experience. In the view of Gynocritics, woman by herself have rights and abilities to assemble their identity without having to be dictated by the society, and regardless of whether the identity is admissible or not. The material objects of this research were Okky Madasari's Entrok and Laksmi Pamuntjak's Amba. In achieving the purpose of the study to reveal the novelty values about the life and identity of women, it is conducted through Gynocritism reading along with content analysis techniques. From the results of the analysis, women authors tries to construct new identity for women which is more credible and balanced for women. This reconstruction is intended to leave the old formed identity that is no longer relevant to the progress of the world of women today.
\end{abstract}

Keywords: identity of women, gynocritics, contemporary novels

\section{Introduction}

Every human being has an identity as a marker which is distinguishing him/her from somebody else. The identity can be physical and non-physical. Non-physical identity is not a permanent and innate thing, but the result of the formation of society. This can be seen from the opinion of Berger \& Luckman [1] and Lindsey [2] who say that identity is a consistent social construction which differs from one individual to another individual [3]. Therefore, socially, identity is the property of an individual, or group of people, as a sign of self or group [4] [5].

Similar situation occurs to identity of women. In patriarchal Indonesian society, women's identities are formed in accordance with the wishes of the surrounding community's agreement. The identification is strongly influenced by cultural values, schools, peers, the mass media, and other family members. For example, a girl in a casual family is encouraged to get to know how to cook, to take care for children or the house compared to a boy. This tendency causes children to inadvertently accept differences in gender-based roles in themselves [6].

Handel, Cahill and Etkin [7] also states that parents are only one of the earliest sources for individuals in learning and understanding gender roles. Through the family, masculine and feminine identities have been introduced since birth [8], [9], [10]. When newborns boys and 
girls have received different treatment, for example girls will be given a pink-colored room and stuffs and boys are given a blue one. That is because pink is identical color to a girl, and blue is identical to a boy [11], [12], [13], [14].

In the history and development of Indonesian literary works, women's identities are mostly adjusted to the ideal picture desired by Androcentric ideology. This can be identified in the works of canonical authors from time to time. A popular example is found in character of Siti Nurbaya who is decorated with features such as soft, obedient, and emotional-oriented. Such uniformity in the portrayal of women has repeatedly been found in novels in Indonesia from the Balai Pustaka era to the most recent era of Indonesian literature [15].

However, there has been a slight movement in the development of contemporary Indonesian literature (especially 2000s until now), where female authors such Ayu Utami, Djenar Mahesa Ayu, Dewi Lestari present works that contain ideas about renewing women's identity [16]. Those authors seek to regain authority of the formation of women's identity today. For example, Ayu Utami's Saman as Dewan Kesenian Jakarta's Best Novel, presents women figures who are brave, strong, and economically independent through the figures Yasmin, Shakuntala, and Laila. Similar case with Okka Rusmini's works that features women who are fearless and even heroic to make decisions that are 'unpopular' in the eyes of the public.

The thesis underlying this research is contemporary literature by women writers have tried to pioneer a new path to formulate the diversity of women's identities; which in this case is represented by Entrok written by Okky Madasari [17] and Amba by Laksmi Pamunjtak [18]. The efforts of these two female authors are manifested by offering new forms for women's identity that are more original than the product of social-orthodox construction. The identity of women displayed in these two novels explore the complexity of the relationship between several aspects of socio-culture that still inhibit the vision of women figures in the vortex of daily conflict. It is hoped that by exploring the experiences of female characters from female authors in these two novels, the creation of a new model of more authentic female literary authorship can be achieved.

\section{Gynocritics Theory}

To answer the problem in this study, Gynocritical paradigm is used as a theoretical framework. This theory was chosen based on the premise that female authors have totally different experiences and orientations from male authors in viewing women and their world [19]. The vision will be seen in the explanations of figures, statements and conflicts narrated in the works. In approaching Entrok and Amba, this paper focused on the discussion on the identity issue constructed by the two women authors.

Gynocriticism initially highlighted women's efforts regarding the definition of identity and social construction especially gender [20]. Showalter [21] added that Gynocritics not only examines women as a certain gender, but also examines the 'internal awareness' of women reflected in women's work or writing. Disclosure of women in terms of subcultures and specific issues of womanhood is a gynocritical focus which consists of women's recognition of women's identity that is free from definition and opposition to masculinity [22]. Therefore in the Gynocritics paradigm, things like class, social interests, political tendencies, religion, and sexuality all of which can be taken into account in the construction of women's identity which is illustrated through women's literary works. 
Gender determination is a way to strengthen the social construction of the division of roles which is considered appropriate because of the different sexes [23]. One of the example is women must take part in the domestic world while men tend to go to the outside world. It was based on the perspective of primitive societies that placed men as hunters and women as gatherers. Such cultural barriers still tend to be accommodated by modern society, especially in the capitalist system. According to feminists, the division of labor based on sex, not only disadvantageous to women but also no longer relevant applied in the life of modern society [24].

Meanwhile, gender is a concept that distinguishes women and men based on sociocultural construction [25]. Because of gender is seen from a socio-cultural perspective, then gender roles arise due to differences in people's perceptions of the tendencies and habits of women and men [26]. That perception is manifested in some social and cultural tasks. Sociocultural construction of men and women makes the identities, roles and relationships of women and men also different. The identity is formed performatively, repeated until the original identity is reached [27]. Finally, constructing gender is not just merely a process, but gender is a certain type of process from a set of repetitive activities.

\section{Methods}

The method used in the selection of research objects is the method of purporsive sampling or the determination of samples with selected goals. It means the selection of research objects is based on the issue of selection discussed regarding the identity of female characters. In analyzing data, the writer conducted content analysis technique which aims to describe the meaning, purpose and tendency of the textual data. Data were interpreted based on identity theory and Showalter's Gynocritical theory, especially regarding women's writing and culture.

\section{Result and Discussion}

Based on Gynocritical reading toward two novels that were the object of research, it was found three contructed women's identities were rarely exposed to the general public. This findings show the efforts of these female authors to provide altered perspectives that are truly in accordance with women's experiences in real life. Since the birth and development of Indonesian literature, the description of women's identity was dictated by the male perspective with stereotypical features such as gentle, affectionate, caregiver, timid, and all the like [28]. Gynocritics then provide the broadest possible space to uncover how other forms of identity, which are sourced from the vision, imagination and experience of female authors. Here are some of the identities proposed in the novel Entrok and Amba.

\subsection{Construction of Women's Identity in Female Literature}

\subsubsection{Prioritizing Education over Domestic Affairs}

The female character in the novel Entrok and Amba is described as aware and independent women that prefers education than 'things that take precedence for women in general' such as marriage or family service [29]. This action is based on an assumption that 
education could change destiny for the better in the future. Here are a several quotation that state that idea:

... mereka harus menunggu setahun lamanya, setelah Amba menyelesaikan ujian akhir SMA-nya. Itu berarti ia baru saja ulang tahun ke delapan belas. Delapan belas dan belum menikah. Di Kadipura itu berarti perawan yang tidak laku. Bagi Nuniek tak ada nasib yang lebih mengerikan, justru karena ia tahu Amba tak akan peduli [18].

$\cdots$

Amba sendiri kukuh dalam pendiriannya. Ia tak hanya ingin lulus, tapi ia ingin lulus dengan luar biasa. Baginya tak ada pilihan lain ia harus masuk universitas. Di kelas tiga SMA, semua siswa tak lagi diharapkan hanya lulus tiga mata pelajaran-matematika, bahasa Indonesia, dan ilmu pasti-tapi diwajibkan masuk sebuah jurusan. Amba masuk "Bagian A"-bahasa [18].

The quote and narration above shows the unusual description of women's identity from the perspective of Indonesian society in general. Generally, women are not permitted to prioritize education because women must put marriage or household matters first [30]. This antagonism is reinforced by the notion that being an old maid is far worse than being an educated woman. In this situation, a new identity is raised about women has the right to proper education and good grades. For Amba, the social life of her surrounding community not yet apart from the old patriarchal values and stigma that cause women lose their basic rights.

This is consisten with Arivia's opinion which states that the actions taken by a person tend to end in public judgment [31]. The society will act as a judge which decides it is appropriate or inappropriate, good and which is not good. This idea is illustrated in the following quote:

Tapi ia tak sudi terpancing. la tak akan membiarkan dirinya termakan

oleh orang-orang bodoh di sekitarnya, dengan pikiran-pikiran mereka yang kuno [18].

The above statement is in line with the views and visions of feminist-socialist criticism. Feminism-socialists call on women as part of the subaltern (oppressed groups) to be aware of the consequences of their exclusion in the midst of the domination of patriarchal society. The process of awareness is one way to arouse the emotions of women so that they change the situation [32]. Next, this effort is infiltrated and manifested into inner resistance. Inner resistance is characterized by showing resentment and anger in the heart, ideas to overhaul social-community structures and cultural values. The rejection of old and conservative ideas that cannot be demonstrated through physical resistance will be delivered through words and actions.

The reason for Amba being unable to express her wishes out loud in front of her parents because of the imbalance of power in the family. Amba, however, is a child who should obeys instructions from both parents. Amba's helplessness made her only fight through inner struggle and mind while quietly continuing her defense and desire. That weakness is the reason why woman is commonly silent about her will. 
This is in compliance with the opinion of Shastri which argues that outside conditions make women unable to speak and will lose because society tends to blame the woman if a problem or conflict occurs [33]. Society is acted as opinions controller of the public. However, humans (especially women) are social creatures who can not be separated from her society and surrounded by long-standing social rules [34].

\subsubsection{Rejecting Class Division based on Gender}

Another construction of women's identities illustrated in both novels can be seen from the women's character resistance towards injustice. Montrose [35] explained that male domination towards women originated from the story of human creation where women are considered to be representatives of weak-defective seed (red) and male is strong-perfect seed (white). This interpretation then developed to make a wide gap between men and women in doing or getting a job and the position in social life [36].

Therefore, gender restrictions are also in conformity with the division of labour. Instead of adopting a gender-based division of labor, Entrok's female character comes up with a different idea. Marni describes as a character who is not legitimating work and wage differences between men and women. That issue is shown through the portrayal of eccentric figures, Marni.

"Ni, kamu ada-ada aja. Nggak ada perempuan nguli. Nggak akan kuat. Sudah, perempuan itu kerja yang ringan-ringan aja. Ngupas singkong." [17].

"Tapi tetap nggak umum, Ni. Di pasar ini, nggak ada perempuan nguli" [17].

Nyai Dimah memang benar. Kepada siapa pun aku bekerja di pasar ini, aku akan diupahi dengan bahan makanan. Lagi pula tak banyak pedagang yang butuh buruh seperti Nyai Dimah [17].

Simbok berkata, aku tak akan mendapat uang. Kebiasaan di pasar, buruh-buruh perempuan diupahi dengan bahan makanan. Beda dengan kuli laki-laki yang diupahi dengan uang [17].

Marni's character is considered to violate the general paradigm by choosing to work as a porter because it is a job that can only be performed by men [37]. Marni does not approve this convention because according to her, anybody is able to do it regardless of their gender. Marni also believes that if Teja's work is paid with money then she also gets the same thing. This logic confirms that women also have the right to want and do a job regardless of the view on gender. This is also illustrated in the following quote:

Teja mendapat satu rupiah untuk setiap barang yang diangkatnya. Kalau sehari dia bolak-balik mengangkat sepuluh kali, dia sudah mendapat sepuluh rupiah. Lima hari bekerja, uang Teja cukup untuk membeli satu entrok. Kenapa aku tidak bekerja seperti Teja? [17]. 
Tapi coba lihat, begitu buruh perempuan itu sampai di rumah. Mereka harus mengerjakan semua pekerjaan yang ada, mengambil air dari sumber dengan menempuh perjalanan naik-turun. Berat satu jun yang berisi penuh air sama saja dengan satu goni berisi singkong. Tidak ada laki-laki yang mengambil air, katanya itu urusan perempuan. Ya jelas lebih enak nguli daripada ambil air. Nguli diupahi duit, sementara mengambil air tidak pernah dapat apa-apa [17].

Marni do not issues this matter because of her antagonism to men. That was more due to her need for money. Marni no longer wants to peel cassava because it will only be paid for food. Meanwhile, Marni wants only to have money to buy an entrok (bra).

In many of Marni's limitations, then the only way to get money is to become coolie laborers. Although the social community where it belongs considers the choice inappropriate for a woman. This is illustrated in the quote below:

Aku pulang dengan puas dan penuh semangat. Bahagia, hanya karena aku mempunyai harapan lagi. Hari itu waktu seperti berjalan lambat. Sudah tidak sabar rasanya untuk kembali ke pasar, nguli, dan mendapat upah. Aku akan segera mempunyai entrok [17]

“... dalam hati aku tetap bertekad akan nguli. Akan kutinggalkan Simbok saat dia sibuk mengupas singkong-singkong Nyai Dimah. Aku akan pergi sebentar-sebentar. Setiap selesai ngangkat barang, aku akan kembali sebentar mengupas singkong. Simbok akan mengira aku kebelet atau bermain dengan anak-anak pasar" [17].

For Marni, the difference in the division of labor and wages should not be related to gender and identity matters. This is so unfavorable to women because it limits their space and creativity [37]. One form of Marni's resistances is to ignore the confrontations of the public. By only focusing on her work, Marni can ease the burden on her mind.

In this case, Marni prefers to manifest her dream as symbolic resistance and efforts to reconstruct the identity of women in the surrounding community. Of course, this must begin while gradually increasing the struggle of women in the recognition of their full individuality. This is in harmony with the opinion that subjective rights and women's authority can only be freed from gender-based antagonism, if the capitalistic economic system is replaced by socialist society namely egalitarian societies without classes [32].

\subsubsection{Work in the Public Sector or Outside the Home}

The identity of Indonesian women has always been synonymous with domestic queen and allergic to work in the public sector. If that thing exists, women still carry their home work as the main obligation. This kind of dilemma lastly makes women reluctant to get away from the house. However, the dilemmatic case as described above was not occur in the novel Entrok and Amba.

Woman as a worker in the public sector is performed by Amba in Amba. In the narration, Amba character shows strong courage in choosing the future she wants. Amba is 
unlike Indonesian women which most of them stay at home and are busy with their domestic work. This situation is illustrated in the following passage:

Tapi Amba akan ingat pada momen itu sebagai sesuatu yang benar dan perlu. Ada yang terasa lengang tapi murah hati di udara, yang mengisi dadanya, seperti sebuah percanda. Kediri akan menjadi ujian. ketahanan baginya, ujian atas tekad dan keberaniannya [18].

$\cdots$

Dia akan pergi. Dia tak akan takut. Dia akan membantu orang lain. Menjadi berguna [18].

...

"Untuk mencoba menjadi berguna, meskipun kuakui tempat itu berbahaya." [18].

Similar path was also taken by the main female character, Marni in Entrok. Marni works outside the house by selling food ingredients around the village. Marni do not bother with that and remained focused on her goal of making money. This effort proves that the Marni figure did not surrender to her fate and tried hard to achieve her financial independence. This is illustrated in the following quote:

Aku akan menjual daganganku di sepanjang jalan pasar sampai ke Singget, lalu berkeliling dari rumah ke rumah yang ada di Singget. Siapa yang masih memilih jalan ke pasar kalau ada yang mengantarkan dagangan ke pintu rumah? [17].

Tak pernah ada cita-cita lain yang diturunkan orangtuaku selain bisa makan hari ini. Tapi aku menyimpan harapan dan mimpi. Setidaknya untuk entrok. Cukup dengan harapan itu aku bisa melakukan apa saja. Dari buruh pengupas singkong menjadi kuli. Dan sekarang terseokseok di bawah panas matahari, mampir ke setiap rumah, menawarkan belanjaan yang hanya sedikit [17].

Marni does not establish herself only as a traveling salesperson. Due to her perseverance and hard work, Marni succeeded in increasing her fortune in the public sector. Alike Amba character who wants to be useful to others, Marni also finally can create jobs for people around her. This is illustrated in the following quote:

Aku berdiri di tengah mereka yang semuanya laki-laki. Dan aku sekarang akan mengupahi mereka. Simbok, lihatlah anakmu ini sekarang. Kita dulu kerja memeras keringat seharian, diupahi telo, bukan uang, hanya karena kita perempuan. Lihatlah sekarang, anakmu yang perempuan ini, berdiri tegak di sini mengupahi para laki-laki [17].

The success of the two female figures in their job and achieving something big in the public sector will slowly remove the bad stigma attached to Indonesian woman which is identical with incompetence and inferiority [38]. This was managed by the two authors in an attempt to regain public confidence regarding abilities and limits that can be achieved by a 
woman. As illustrated by the two leading figures, women have their own ways and ways to realize their determination. Through this counter-discourse, the women's movement to prove themselves and achieve their desires can no longer be hindered.

\subsection{The Background on the Birth of Women's Identity in Women}

\section{Literature}

The construction of woman's identities in female literary works is quite distinctive. There are several reasons why women create such identities in their literary works which differ from the normative conditions found in society. Even in a few moments, these women characters dare to put up a challenge to what they disagree with which is very rarely seen in real life. The following are some of the reasons for the emergence of these women's objection.

\subsubsection{Factor of Community's Social System}

In Entrok, discrimination experienced by Marni character is caused by socio-cultural factors which still clashes between the male and female. This perspective-one of which-is manifested through drawing a line between jobs suitable for men and women. In the narration, Marni expressed her desire to work in order to get money to buy entrok, not to rival men. However, her desire was misinterpreted by the paradigm of societywhich is revealed by Simbok in the following quote:

Waktu aku ceritakan rencanaku pada Simbok, dia langsung menolaknya. "Nduk, semua itu sudah ada jatahnya. Orang kayak kita bagiannya ngoncek telo. Nguli itu berat. Sudah jatah orang lain" [17].

In Marni's community, people assume that heavy work is only for men. In addition, only work of men should also be paid with money because men should support their families. In this case, a job in the Marni community also has appropriate and inappropriate parameters. This is illustrated in the following quote:

Aku malas melanjutkan omongan karena merasa tidak akan ada gunanya. Kalau Simbok sudah menyebut ilok-ra ilok, itu berarti pakem yang sudah tidak bisa dibantah lagi [17].

Marni's portrayal of characters who try to get out of social conditions that disadvantages her is a spirit of the age and also as a symbolic movement of women in the modern era. Gopur [39] states that many factors make women go beyond obsolete rules in society in recent decade. One of them is caused by many women who have been educated and forward thinking to achieve equality of opportunity in several field especially economics and politics.

However, social factors and views of life existed in society are also something that have been entrenched for a long time. The act of rejection this matter and replacing it with a newer angle cannot be done immediately. The issue is also illustrated in Amba's novel: 
Ia tak punya kesabaran terhadap perempuan yang membiarkan arti hidupnya ditentukan oleh hubungannya dengan suami, calon suami, atau yang berharap jadi suami [18].

Amba character openly stated her disagreement toward the old-system in the her community which views women as a status symbol of husband's position. This thing is not logical for Amba. Amba wants to create her own identity regardless of her husband because both are different entities. This is illustrated in the following quote:

Ia tak punya kesabaran terhadap perempuan yang membiarkan arti hidupnya ditentukan oleh hubungannya dengan suami, calon suami, atau yang berharap jadi suami [18].

\subsubsection{Factor of Family Pressure}

The family has long been seen as one of the most effective institutions for instilling certain values and ideologies [40]. In the family, members who take shelter under it must follow a general narrative which is dominantly controlled by 'adult male figures' (such as father or adult man). This hirarchy made Marni character realize that women will always be the object of oppression because of their inferior position. This is recorded in the following quote:

Samar-samar dalam ingatanku, terbayang Bapak memukul Simbok yang sedang sakit panas dan tidak bisa ke pasar. Kalau Simbok tidak ke pasar, kami tidak akan punya makanan. Dan laki-laki itu dengan seenaknya hanya menunggu makanan. Dia seperti anjing gila yang marah saat kelaparan. Ya, dia memang anjing gila [17].

The power of male in Marni's family is described as unlimited although he do not perform his function as a breadwinner for his family. This privilege is never owned by women in a family unit. With this advantages, women will continue to be silenced (physically and mentally) if it does not satisfy the expectations of the man. This mechanism it is often used as a weapon by men to emphasize 'man-always-right' ideology. This is illustrated in the following quote.

Saat itu aku ketakutan. Menyembunyikan diri di balik pintu sambil menangis sesegukan. Laki-laki itu pergi setelah menghajar istrinya dan tak pernah kembali lagi [17].

This is in line with Fakih's argument [34] that restrictions on the role of women by a certain ideology will make subordinate women through discriminatory treatment. This inequality between the roles of men and women has become one of the structural obstacles which causes individuals in society not to have the same access. In addition, the lack of legal protection for women indirectly has also placed the position of women into marginalized and 
often as the victim. Amba character acknowledges this opinion through the following contemplation:

"Siapa yang akan kusalahkan? Diriku sendiri? Atau bapakku yang bodoh yang mengatur siapa yang harus kupilih? Mungkin ini semua salahku! Mengapa tak kulemparkan tubuhku di depan kereta perang Bhisna yang menderu, ketika pertempuran sengit itu berlangsung menghadapi Salwa?" [18].

"Bapak mengajarkan anak-anak Bapak ndak bersyukur atas rahmat Tuhan!

Atas berkah dan perlindungan-Nya! Emangnya Bapak ingin menjebloskan anak sulung kita ke tengah-tengah api neraka!" [18]

Amba called for protests above due to pressure from her family. She did not get the right to choose her own partner, not free from the dominance of her parents at home. Her position as a child made Amba not have the freedom in deciding her life. This is in line with the opinion of Dingwall [41] that parents often perceive that they have absolute rights toward the lives of their children so that it makes children depressed and unable to express their choices.

\subsubsection{Faktor Kebijakan Publik/Politik}

Female characters frequently received unfair treatment when they chosed to work outside/in public because of political or government policy that is unaffected towards poor and subordinate party like Marni character. The state uses its power and position like male figure to make people afraid and obey their orders. Common people, like an opressed female groups, can only obey the command. This case is illustrated in the following quote.

"Ya monggo. Lima ribu dibayar tiga puluh kali."

Mbakyu, sampeyan sudah berjualan di sini. Kata komandan saya, sampeyan harus bayar uang keamanan," kata laki-laki berseragam loreng itu. Dia datang lagi bersama dua temannya. "Makyu, masa aku disamakan dengan orang lain. Kamu lihat seragamku, lihat pistol ini?" [17]

Marni witnessed the wicked deeds of the state apparatus with her own eyes. The state that should be present as a protector and a provider for the people, instead acting as an antagonist in this case. This action is further exacerbated by the notion that women are easy targets to be bullied. This is also illustrated in the following quote:

"Mbakyu, sampeyan sudah berjualan di sini. Kata komandan saya, sampeyan harus bayar uang keamanan," kata laki-laki berseragam loreng itu. Dia datang lagi bersama dua temannya. Tentara-tentara itu mengambil dagangan Ibu. Masih ada empat ember dan enam panci, 
semuanya ludes. Mereka juga mengambil setengah karung beras. Bapak Ibu diam saja tidak berbuat apa-apa [17].

The explanation above is in line with Fakih [34] and Widayani \& Hartati [42] that government policy products never accommodate the needs of women in public eye. Ultimately, it generally makes women as victims of these policies. Historical and cultural aspects place women as those who are subjugated through patriarchal power relations, both personally and state regulation.

\section{Conclusion}

The emergence of female writers in recent Indonesia literature has made the pattern of feminist criticism shift to the study of Ginocritics. This effort have some aims such as to promote new feminine-base values and formulas offered by the women's contemporary literary works without having to follow again or copy the masculine model. Through this way, feminist criticism began to focus on the scope of women's experience and vision alone without cornering patriarchal ideology or confrontagonism with the world of men anymore. With this kind of limitation, it is hoped that the values and novelty of authentic women's literature can be achieved.

Based on the result of the analysis of the two novels Entrok and Amba, Pamuntjak and Madasari (female writers) are seen trying to offer more credible and factual identities for women to the public through the life stories of the two main characters. The renewal is manifested by promoting identities that have been marginalized, hidden or denied from public knowledge such as strong, logical, progressive and humanist. The emergence of these progressive voices has been motivated by the insistent pressure originating from socio-cultural factors, family pressures and improper public policies toward women. These pressures make women more excited and determined to walk off the timeworn life model by reconstructing a brand new identity.

\section{Acknowledgement}

The author(s) disclosed receipt of the following financial support for the research, authorship, and/or publication of this article: This work was supported by the Research and Community Service Council (LP2M) of Universitas Negeri Padang grant number 182/UN.35/LT/2019 fiscal year 2019.

\section{Citation and References}

[1] P. T. Berger and T. Luckman, The Social Construction of Reality: A Treatise In The Sociology Of Knowledge. Connecticut: Tantor Media, 2017.

[2] L. L. Lindsey, Gender Roles: A Sociological Perspective (6th Edition). New York: Routledge, 2015.

[3] P. J. Burke, Contemporary Social Psychological Theories. California: Stanford University Press, 2018.

[4] P. J. Burke, and J. E. Stets, Identity Theory. Oxford University Press, 2009. 
[5] M. J. Carter, and D. C. Mireles, "Identity Theory." The Blackwell Encyclopedia of Sociology, 2015. https://doi.org/10.1002/9781405165518.wbeosi078.

[6] C. L. Ridgeway and L. Smith-Lovin, The gender system and interaction. Annual Review of Sociology vol. 25 pp. 191-216, 1999.

[7] G. Handel, S. Cahill, and F. Elkin, Children and Society: The Sociology of Children and Childhood Socialization. NY: Oxford University Press, 2007.

[8] L.C. Bell, "Psychoanalytic Theories of Gender." In The Psychology of Gender. Edited by Alice H. Eagly, Anne H. Beall and Robert J. Sternberg. New York: The Guilford Press, 2004.

[9] G. W. Peterson, and D. Hann, "Socializing children and parents in families." In Handbook of Marriage and the Family (2nd edition). Edited by M. B. Sussman, S. K. Steinmetz and G. W. Peterson. New York: Plenum Press, pp. 327-70, 1999.

[10] M. M. Messner, "Barbie Girls Versus Sea Monsters: Children Constructing Gender," Gender and Society vol. 14. pp. 765-84, 2000.

[11] A. C. Hurlbert and Y. Ling. "Biological components of sex differences in color preference," Current biology, vol. 17, no. 16, 2007R623-R625, 2007.

[12] V. LoBue, and J. S. DeLoache, "Pretty in pink: The early development of gender-stereotyped colour preferences," British Journal of Developmental Psychology. vol. 29, no. 3, pp. 656-667, 2011.

[13] C. Taylor, A. Clifford, and A. Franklin, 2013. "Color preferences are not universal," Journal of Experimental Psychology: General. vol. 142, no. 4, pp. 1015, 2013.

[14] K. Dzida, "Genderisation of Colour: The Pink and Blue Project," Culturescope vol. 111, pp. 16-17, 2017.

[15] Y. Asri, and Y. Hayati, "Construction of Women's Roles in Patriarchal Culture (Feminist Study towards Modern Indonesian Novels)." Proceedings of the Second Conference on Language, Literature, Education, and Culture (ICOLLITE 2018). https://doi.org/10.2991/icollite-18.2019.8, 2019.

[16] A. Priyatna, "Feminist Voice in the Works of Indonesian Early Woman Writers: Reading Novels and Short Stories by Suwarsih Djojopuspito," Journal of International Women's Studies, vol. 19, no. 2, pp. 230-243, 2018

[17] O. Madasari, Entrok. Jakarta: Gramedia Pustaka Utama, 2015.

[18] L. Pamuntjak, Amba. Jakarta: Gramedia Pustaka Utama, 2012.

[19] P. Morris, Literature and Feminism: An Introduction. Oxford: Blackwell, 2000.

[20] P. Barry, Beginning Theory: An Introduction to Literary and Cultural Theory. Manchester: Manchester University Press, 2009.

[21] E. Showalter, "Feminist Criticism in the Wilderness". Critical Inquiry. Vol. 8, no. 2. Writing and Sexual Difference. The University of the Chicago Press, pp. 179-205, 1981.

[22] E. Showalter, The New Feminist Criticism: Essays on Women, Literature, and Theory. New York: Pantheon Books, 1985.

[23] M. L. Anderson, Thinking About Women: Sociological Perspectives on Sex and Gender. New York: Allyn \& Bacon, 2003.

[24] L. Lamphere, "The Domestic Sphere of Women and the Public World of Men: The Strengths and Limitations of an Anthropological Dichotomy," pp. 86-95. In Gender in cross-cultural perspective. New Jersey: Prentice Hall, 1993.

[25] K. Bhasin, Understanding Gender. New Delhi: Women Unlimited, 2009.

[26] H. M. Lips, Sex and Gender: An Introduction. Waveland Press, 2017. 
[27] J. Butler, Gender Trouble: Feminism and the Subversion of Identity (Tenth Anniversary Edition). London: Routledge, 2014.

[28] L. J. Sears, Fantasizing the Feminine in Indonesia. London: Duke University Press, 1996.

[29] A. D. Saputra, "Perempuan Subaltern dalam Karya Sastra Indonesia Poskolonial". LITERASI: Indonesian Journal of Humanities. vol. 1 no. 1, 16-30, 2011.

[30] K. M. Robinson, and S. Bessel (Eds.). Women in Indonesia: Gender, equity and Development. Institute of Southeast Asian Studies, 2002.

[31] G. Arivia, Filsafat Berspektif Feminis. Jakarta: Yayasan Jurnal Perempuan, 2005.

[32] R. Megawangi, Membiarkan Berbeda? Sudut Pandang Baru tentang Relasi Gender. Bandung: Mizan Pustaka, 1999.

[33] A. Shastri, Gender Inequality and Women Discrimination. IOSR Journal of Humanities and Social Science (IOSR-JHSS), vol. 19, pp.28, 2014.

[34] M. Fakih, Analisis Gender dan Transformasi Sosial (15th edition). Yogyakarta: Insist Press, 2016.

[35] L. A. Montrose, "Shaping Fantasies": Figurations of Gender and Power in Elizabethan Culture. Representations. https://doi.org/10.2307/2928384, 1983.

[36] S. Cohn, Race, Gender, and Discrimination at Work. London: Routledge, 2019.

[37] K. Sohn, "Gender Discrimination in Earnings in Indonesia: A Fuller Picture," Bulletin of Indonesian Economic Studies, vol.51, no.1, pp. 95-121, 2015

[38] I. A. G. Azmi, S. H. S. Ismail, and S. A. Basir, Women Career Advancement in Public Service: A Study in Indonesia. Procedia - Social and Behavioral Sciences. https://doi.org/10.1016/j.sbspro.2012.09.1004, 2012.

[39] A. Gopur, Pergeseran Peran dan Tanggungjawab Wanita dalam Keluarga TKW. Skripsi. Yogyakarta: UIN Sunan Kalijaga, 2010.

[40] L. Althusser, "Ideology and Ideological State Apparatuses (Notes towards an Inrestigation)," Media and Cultural Studies: Keyworks, vol. 80, 2012.

[41] R. Dingwall, J. Eekelaar, and T. Murray, The Protection of Children: State Intervention and Family Life. Vol. 16. Quid Pro Books, 2014.

[42] N. M. Widayani, and S. Hartati, "Kesetaraan dan Keadilan Gender Dalam Pandangan Perempuan Bali: Studi Fenomologis Terhadap Penulis Perempuan Bali,"Jurnal Psikologi Undip, vol. 13, no. 2. pp. 149-162, 2015. 